\title{
A Null Mutation of the Serotonin 6 Receptor Alters Acute Responses to Ethanol
}

\author{
Stephen J Bonasera ${ }^{1,5}$, Hung-Ming $\mathrm{Chu}^{2,3,5}$, Thomas J Brennan ${ }^{4}$ and Laurence $\mathbf{H}$ Tecott*,3 \\ 'Division of Geriatrics, Department of Medicine, University of California, San Francisco, San Francisco, CA, USA; ${ }^{2}$ Community Behavioral Health \\ Services, Chinatown/North Beach Mental Health Services, San Francisco, CA, USA; ${ }^{3}$ Department of Psychiatry, University of California, \\ San Francisco, CA, USA; ${ }^{4}$ Five Prime Therapeutics Inc., San Francisco, CA, USA
}

\begin{abstract}
The anatomical distribution and pharmacology of serotonin 6 receptors (5- $\mathrm{HT}_{6} \mathrm{Rs}$ ) implicate them as contributors to the serotonergic regulation of complex behavior. To complement the limited range of pharmacological tools available to examine $5-H_{T} T_{6} \mathrm{R}$ function, we have generated a mouse line bearing a constitutive null mutation of the $5-\mathrm{HT}_{6} \mathrm{R}$ gene. No perturbations of baseline behavior were noted in a wide array of assays pertinent to multiple neurobehavioral processes. However, $5-\mathrm{HT}_{6} \mathrm{R}$ mutant mice demonstrated reduced responses to the ataxic and sedative effects of ethanol. No differences in ethanol metabolism were evident between wild-type and $5-\mathrm{HT}_{6} \mathrm{R}$ mutant mice. These findings implicate $5-\mathrm{HT}_{6} \mathrm{Rs}$ in the serotonergic modulation of responses to ethanol.

Neuropsychopharmacology (2006) 3 I, I80 I-1813. doi:I0.1038/sj.npp. I30 I030; published online I February 2006
\end{abstract}

Keywords: receptors; serotonin; 5-HT6; 'knockout' mouse; ethanol tolerance; loss of righting reflex; ataxia

\section{INTRODUCTION}

Serotonin (5-hydroxytryptamine, 5-HT) is an important regulator of many complex neuropsychological processes, including affect, exploration, motivation, feeding, and responses to substances of abuse (Aghajanian and Sanders-Bush, 2002; Barnes and Sharp, 1999). To date, 14 serotonin receptor subtypes that mediate the CNS actions of 5-HT have been identified (Hoyer et al, 1994; Barnes and Sharp, 1999). The functional significance of a number of these receptor subtypes remains unclear. This is the case for the $5-\mathrm{HT}_{6} \mathrm{R}$, a G-protein-coupled receptor that is positively linked to the adenylate cyclase second messenger system (Monsma et al, 1993; Ruat et al, 1993; Kohen et al, 1996; Branchek and Blackburn, 2000). Receptor expression in rats, guinea pigs, and humans appears CNS-limited and most prominent in the caudate-putamen, nucleus accumbens, and olfactory tubercle, with lesser expression in the hippocampus, cortex, and amygdala (Monsma et al, 1993; Ruat et al, 1993; Ward et al, 1995; Kohen et al, 1996; Roberts et al, 2002). Several classes of psychotropic drugs such as atypical antipsychotics, tricyclic antidepressants, and

\footnotetext{
*Correspondence: Dr LH Tecott, Department of Psychiatry, University of California, San Francisco, San Francisco, CA 94I43, USA, Tel: + I 4154767858 , Fax: + I 4154760526 ,

E-mail: larry.tecott@ucsf.edu

${ }^{5}$ These authors contributed equally to this work.

Received 29 March 2005; revised 12 October 2005; accepted 26 October 2005

Online publication: 23 December 2005 at http://www.acnp.org/ citations/Npp I 223050502 I I/default.pdf
}

hallucinogens bind with high affinity to $5-\mathrm{HT}_{6} \mathrm{Rs}$ (Monsma et al, 1993; Roth et al, 1994; Glatt et al, 1995). Thus, the expression pattern and pharmacological properties of $5-\mathrm{HT}_{6} \mathrm{Rs}$ indicate that they may contribute to serotonergic modulation of clinically relevant neuropsychological processes and psychopharmacological responses. Administration of $5-\mathrm{HT}_{6} \mathrm{R}$ antagonists and antisense oligonucleotides have been reported to produce several behavioral effects in rodents, including feeding suppression (Svartengren et al, 2004), yawning and stretching (Bourson et al, 1995; Sleight et al, 1996; Sleight et al, 1998; Bentley et al, 1999), decreased anxiety-related behaviors (Hamon et al, 1999), and improved performance in learning and memory tasks (Meneses, 2001; Rogers and Hagan, 2001; Woolley et al, 2001; Russell and Dias, 2002; Lindner et al, 2003; Riemer et al, 2003).

The prominent expression of $5-\mathrm{HT}_{6} \mathrm{Rs}$ within dopaminergic terminal fields (Boess et al, 1998; Gérard et al, 1997; Hamon et al, 1999), including the nucleus accumbens, raises the possibility that these receptors may also play a role in the serotonergic modulation of responses to substances of abuse. Rats treated with $5-\mathrm{HT}_{6} \mathrm{R}$ antagonists showed greater sensitivity to the locomotor and reinforcing effects of amphetamine, and elevated extracellular dopamine in the prefrontal cortex compared to those treated with vehicle (Frantz et al, 2002).

Genetic association studies also suggest that specific $5-\mathrm{HT}_{6} \mathrm{R}$ polymorphisms may be associated with several major neuropsychiatric diseases, including schizophrenia (Tsai et al, 1999a; however, see Shinkai et al, 1999; Ohmori et al, 2001) and Alzheimer's disease (Tsai et al, 1999b; 
however, see Thome et al, 2001). 5- $\mathrm{HT}_{6} \mathrm{R}$ polymorphisms may also influence clinical responses to atypical antipsychotic drugs (Lane et al, 2004).

To examine functional roles of $5-\mathrm{HT}_{6} \mathrm{Rs}$, we used a gene targeting approach to produce mice constitutively lacking these receptors. Although extensive assessment of these animals revealed no abnormalities of baseline behaviors, marked abnormalities were observed in behavioral responses of these animals to ethanol. We report that mice lacking $5-\mathrm{HT}_{6} \mathrm{Rs}$ have decreased sensitivity to ethanolinduced ataxia and sedation, and increased ethanol-induced open field locomotion. These findings suggest that $5-\mathrm{HT}_{6} \mathrm{R}$ activity might influence susceptibility to the effects of ethanol.

\section{MATERIALS AND METHODS}

\section{Targeting Vector}

An $11 \mathrm{~kb}$ DNA fragment encoding the first exon of the htr6 gene was obtained from a 129 mouse P1 bacteriophage library (gift from Drs Mark Hamblin and Ruth Kohen, Seattle, WA). Within this fragment, a $300 \mathrm{bp} P s t \mathrm{I}-P s t \mathrm{I}$ segment encoding a portion of the $5-\mathrm{HT}_{6} \mathrm{R}$ protein from the middle of the third to the end of the fifth transmembrane domain was deleted and replaced by a neomycin-resistance gene cassette (NEO) driven by a phosphoglycerate kinase (PGK) promoter (PGK/NEO). A herpes simplex virus thymidine kinase (TK) gene driven by a PGK promoter (PGK/TK) was placed at the $3^{\prime}$ end of the genomic sequence to complete the p5HT6TKN targeting construct (Figure 1a).

\section{Generation of Homologous Recombinant Clones}

The p5HT6TKN construct was linearized and electroporated into 129-derived JM1 embryonic stem (ES) cells (gift of Dr Roger Pedersen), followed by application of a standard positive-negative selection strategy (Mansour et al, 1988) to enrich for targeted clones. The resulting ES cell colonies were screened for homologous recombination by Southern blot analysis. A genomic fragment (HindIII-XbaI) corresponding to a region $3^{\prime}$ to the expected integration site was used to probe genomic DNA digested with XbaI. Wild-type and mutant alleles were indicated by 11 and $7.5 \mathrm{~kb}$ fragments, respectively (Figure 1a and b). Greater than $6 \%$ of drug-resistant clones had undergone homologous recombination, as confirmed by Southern blotting using the indicated $5^{\prime}$ probe with $\mathrm{XbaI}$-digested genomic DNA (data not shown).

\section{Generation of 5- $\mathrm{HT}_{6} \mathrm{R}$ Null Mutant Mice}

Male chimeras produced by injection of targeted ES cells into C57BL/6J blastocysts were bred with C57BL/6J females. Germline transmission of the targeted mutation was verified by Southern blot analysis of tail DNA from F1 offspring. Experimental animals were derived from heterozygote crosses to produce wild-type, heterozygous, and homozygous mutant mice (Figure 1c). All mice used in these studies had a C57BL/6J allelic contribution of $\geqslant 75 \%$. Animal care and handling procedures were in accordance with the UCSF institutional guidelines and federal regulations.

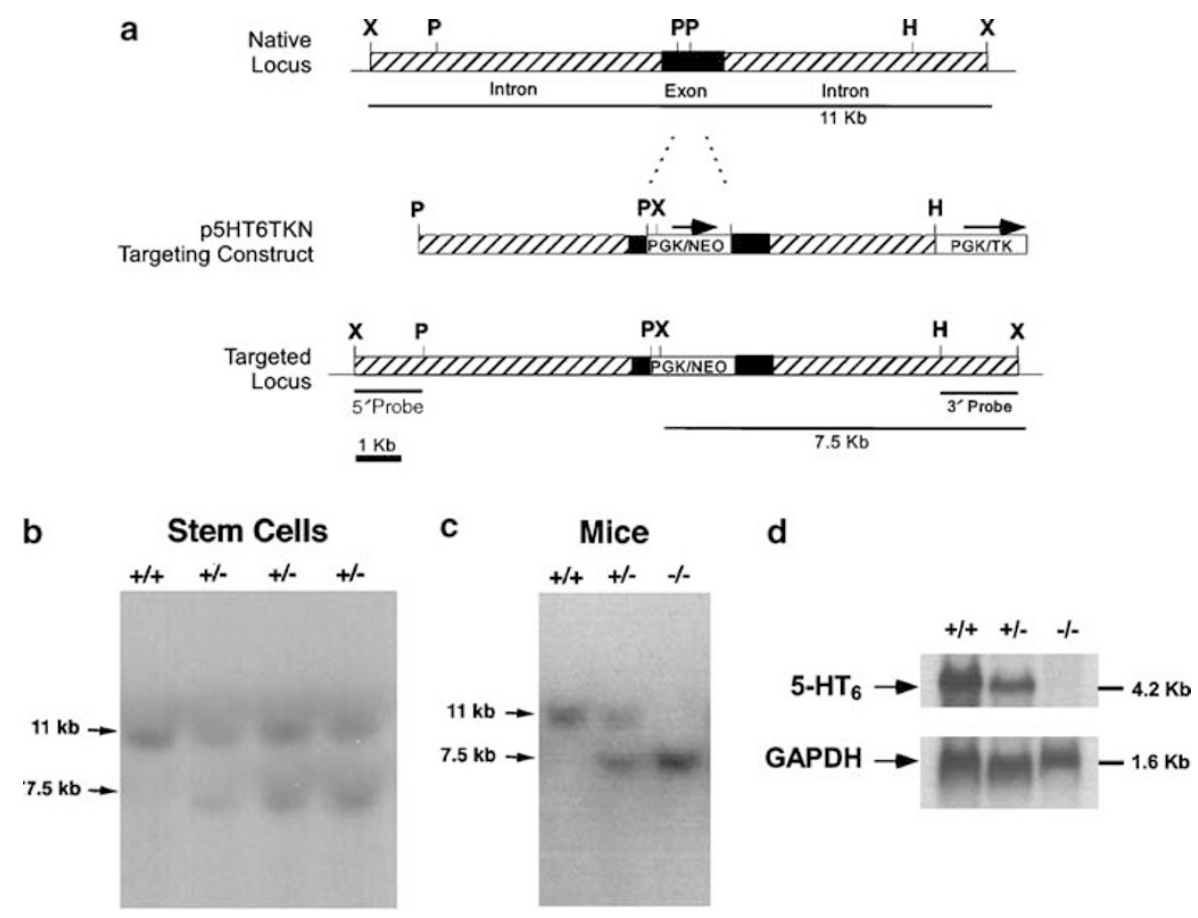

Figure I Production of $5-\mathrm{HT}_{6} \mathrm{R}$ null mutant mice. (a) A schematic representation of the native allele, targeting vector, and mutant allele following homologous recombination. The 7.5 and II kb fragments obtained from Southern blotting are highlighted. (b) A representative Southern blot of Xbaldigested ES cell genomic DNA; the wild-type allele is indicated by an II kb fragment, while the mutant allele is indicated by a $7.5 \mathrm{~kb}$ fragment. (c) A representative Southern blot of Xbal-digested genomic DNA in wild-type $(+/+)$, heterozygous $(+/-)$, and mutant $(-/-)$ mice. (d) A representative Northern blot of whole brain polyA ${ }^{+}$RNA in wild-type, heterozygous, and mutant mice. X: Xbal, P: Pstl, H: Hindlll, PGK: phosphoglycerate kinase, TK: thymidine kinase, NEO: neomycin-resistance cassette. 


\section{Northern Blot Analysis}

Total RNA was extracted with Trizol reagent (Life Technology) from whole brains. From these total RNAs, poly $\mathrm{A}^{+}$RNA was purified using an oligo dT column as described (Sambrook et al, 2001). Nine micrograms of poly $\mathrm{A}^{+}$RNA were run on a formaldehyde gel and transferred to a Duralon-UV membrane (Stratagene), which was then hybridized with a ${ }^{32} \mathrm{P}$-radiolabeled DNA probe corresponding to the $300 \mathrm{bp}$ portion of the htr6 coding region that had been deleted from the targeting vector. Following hybridization, washes and film development, blots were stripped and rehybridized with a GAPDH probe for an internal standard.

\section{Behavioral Testing}

Mice were group-housed (4-6 mice per cage) in standard polycarbonate mouse cages $(29 \times 18.5 \times 13 \mathrm{~cm})$ with free access to food and water under a $12 \mathrm{~h}$ light/dark cycle. Behavioral assays were performed using male mice between the ages of 3 and 6 months. Unless otherwise indicated, naïve mice were used for each behavioral assay, and cohorts of size $n=8$ were used for each group. Between subjects, testing apparatus were cleaned with a $0.25 \%$ bleach solution, wiped down with water, and then dried. All animals were tested during the light cycle. All experimental conditions were counterbalanced by genotype. Approximately 3 min before each assay, animals were removed from their home cage and placed in a clean holding cage for transfer, except for photobeam activity monitoring, where animals were placed into the test chambers directly from home cages. For all behavioral tests, investigators were blind to genotype and drug treatment.

\section{Open Field}

A 4-unit open field was used, consisting of a white Kydex box divided into four separate $50 \times 50 \times 38 \mathrm{~cm}$ chambers, allowing four animals to be tested concurrently. A video camera was mounted directly above the chambers to monitor animals' activity and movement. Four mice were briefly kept in individual holding cages before being simultaneously placed into the open field chambers. Distance traveled was assessed for $30 \mathrm{~min}$ with a video tracking system (Poly-track, San Diego Instruments). Assignments to the four chambers were counterbalanced by genotype. Mouse activity within $7 \mathrm{~cm}$ of the chamber walls was defined as occurring within the peripheral zone; activity further from the walls was considered to occur within the center zone.

\section{Elevated Zero Maze}

A zero maze $(34 \mathrm{~cm}$ inner diameter, $46 \mathrm{~cm}$ outer diameter, on four-braced legs $40 \mathrm{~cm}$ off the ground) was used according to the procedures previously described (Heisler et al, 1998). Mice were removed from their home cage to a transfer cage, and then placed in the center of one of the closed quadrants. Latency to enter an open quadrant (all four paws), time spent in open quadrants, number of closed-to-open quadrant transitions, and head dips were live-scored in a blinded fashion during the 6 min test by a remote observer.

\section{Home Cage Activity}

Animals were housed individually in rat cages $(48 \times 27 \times 13 \mathrm{~cm})$ with bedding, food and water, under a $12 \mathrm{~h}$ light/dark cycle. To assess activity, beam breaks were collected each hour for 3 days with a photobeam activity system (FlexField, San Diego Instruments). Both horizontal locomotor activity (as monitored by a $4 \times 8$ array of infrared photobeams) and rearings (as scored by an elevated set of eight infra-red photobeams) were recorded. The animals were placed in the system at noon on day 1 .

\section{Prepulse Inhibition}

Acoustic startle responses and prepulse inhibition of acoustic startle were evaluated using SR-LAB hardware and software (San Diego Instruments). Mice were placed in clear acrylic testing chambers within the startle chambers. Chambers were not lit during testing. All subjects received a 5 min acclimation period where the only input stimulus was $70 \mathrm{~dB}$ background white noise. Following this acclimation, mice were briefly habituated to six $120 \mathrm{~dB}$ startle stimuli ( $0 \mathrm{~ms}$ rise time, $40 \mathrm{~ms}$ plateau, $0 \mathrm{~ms}$ fall time). Startle habituation was followed by prepulse-startle trials. Prepulse stimulus intensities were 4,8 , or $16 \mathrm{~dB}$ above the $70 \mathrm{~dB}$ background ( $0 \mathrm{~ms}$ rise time, $20 \mathrm{~ms}$ plateau, $0 \mathrm{~ms}$ fall time), and preceded the $120 \mathrm{~dB}$ startle stimulus by $80 \mathrm{~ms}$. During the session, 10 trials each of all three prepulse conditions, as well as control $120 \mathrm{~dB}$ startle stimuli presented without a prepulse, and trials of no stimulation (which provide an upper bound on the maximum prepulse inhibition possible) were randomly interspersed and separated by an average of $150 \mathrm{~s}$ (range 70-230 s). Peak startle responses were detected and measured by piezoelectric sensors located under the testing chambers.

\section{Morris Water Maze}

Three cohorts of 24 animals each (eight per genotype) were trained using a visible platform/hidden platform version of the water maze task. Prior to each training session, mice were removed from their group cages and individually housed in holding cages for the duration of that day's training (approximately $6 \mathrm{~h}$ ). Investigators were blinded to mouse genotype throughout training and testing. An $8 \times 8 \mathrm{~cm}$ clear Plexiglas platform with an attached $7.5 \times 7.5 \times 7.5 \mathrm{~cm}^{3}$ black Plexiglas cube (visible platform) was centered in a randomly selected quadrant of a circular, $92 \mathrm{~cm}$ inner diameter polyethylene tank filled with warm water made opaque using white tempura-based paint (DryTemp powder tempura). Multiple objects were placed in the testing room to act as distal cues; these cues remained constant through all experiments. In one training block, a mouse was gently transported from its holding cage and released into the water facing the maze wall. Swimming paths were videotaped and analyzed using a commercially available software package (EthoVision, Noldus Inc.). The trial ended when the mouse mounted the platform with all four paws or if the mouse did not mount the platform after 
$60 \mathrm{~s}$ of swimming. All mice spent $20 \mathrm{~s}$ on the platform before returning to the holding cage. Following a 1-min rest interval, the mouse was returned to the maze at a different starting quadrant and the above process repeated until all four quadrants had been tested over four trials. Each mouse underwent two blocks of training per day. On day 3 (block 5 ), the visible platform was replaced by an $8 \times 8 \mathrm{~cm}$ clear Plexglas platform submerged $0.5-1 \mathrm{~cm}$ below water level (hidden platform). All mice received 5 days (10 blocks) of training to the hidden platform. Once all mice completed the final training block, the hidden platform was removed from the maze, and all mice received a 1-min probe trial starting from the maze location opposite the old platform position. Probe trials for two of the cohorts were performed immediately after the final block of hidden platform testing; the probe trial for the remaining cohort was performed 28 days after the final day of hidden platform testing.

\section{Motor Coordination}

Motor coordination was assessed with an Accurotor rotarod (Accuscan Instruments). The rotation rate was accelerated from zero to $30 \mathrm{rpm}$ over $5 \mathrm{~min}$, and continued at $30 \mathrm{rpm}$ for 5 more minutes until the end of one trial. Four animals were tested concurrently in separate $11 \mathrm{~cm}$-wide compartments on a rod approximately $3 \mathrm{~cm}$ in diameter and elevated $35 \mathrm{~cm}$. Each animal was assessed over seven trials with 20-min intertrial intervals. In each trial, the latency to fall from the rod was recorded.

\section{Physostigmine-Induced Stretching and Yawning}

Wild-type, heterozygous, and homozygous mutant mice were individually transferred to a holding cage where they received an intraperitoneal (i.p.) injection of either saline vehicle or the cholinesterase inhibitor physostigmine at 0.2 and $0.4 \mathrm{mg} / \mathrm{kg}$ ( $n=8$ per genotype-dosage combination). Yawning, stretch-attend, and locomotor behaviors were continuously scored for $1 \mathrm{~h}$ following injection.

\section{Locomotor Response to Amphetamine}

Wild-type, heterozygous, and homozygous mutant mice were transferred to rat cages and habituated for $120 \mathrm{~min}$, prior to receiving an i.p. injection of saline on day 1 and amphetamine $10 \mathrm{mg} / \mathrm{kg}$ (high dose) on day 2. Additional wild-type and homozygous mutant mice were transferred to rat cages and habituated for $120 \mathrm{~min}$ prior to receiving an i.p. injection of saline on day 1 , and saline or amphetamine $2 \mathrm{mg} / \mathrm{kg}$ (low dose) on day 2 . Mice receiving saline on day 2 received amphetamine $2 \mathrm{mg} / \mathrm{kg}$ on day 9 , and vice versa. Cages were positioned on the photobeam activity system; locomotor activity and rearing were recorded for $120 \mathrm{~min}$ before and $60 \mathrm{~min}$ after i.p. injection. One cohort of 16 mice each (eight wild type, eight mutant) received high-dose amphetamine; two cohorts received low-dose amphetamine.

\section{Ethanol-Induced Ataxia}

The Accurotor rotarod apparatus was used as described above with the following modification in procedure. Before initiation of rotation, mice were placed on the stationary rod facing opposite the direction of rotation, and within $10 \mathrm{~s}$ the rod speed was increased to $8 \mathrm{rpm}$. Each mouse was tested on the rotating rod for a maximum of $100 \mathrm{~s}$. Each mouse was tested in the following sequence: day 1-training session, day 3-saline session 1 , day 5 -saline session 2 , day 8 -ethanol $1.5 \mathrm{~g} / \mathrm{kg}$, day 12 -ethanol $2 \mathrm{~g} / \mathrm{kg}$, day 16 -ethanol $2.5 \mathrm{~g} / \mathrm{kg}$. On the training day, mice were tested for their ability to stay on the rotating rod for more than $100 \mathrm{~s}$ for three out of 10 trials with each trial at least 2 min apart. None of the tested mice failed to meet this criterion. On the saline and ethanol test days, mice were first given one test on the rod, followed by i.p. injection of either saline or ethanol and tested 15 min later.

\section{Ethanol-Induced Loss of Righting Reflex (LORR)}

Mice were injected with $3.5 \mathrm{~g} / \mathrm{kg}$ i.p. ethanol and put in a supine position in a plastic $\mathrm{V}$-shaped trough. LORR was confirmed when the animals failed to right themselves and stand on all four paws for three times within a 30-s period. The length of LORR was recorded for each mouse. The test sequence of mice was counterbalanced by genotype.

\section{Locomotor Response to Ethanol}

Mice were tested in a photobeam activity system (FlexField, San Diego Instruments) configured to monitor both horizontal locomotor activity and rearings. In each test session, mice were habituated in the activity chamber for $2 \mathrm{~h}$ followed by i.p. injection of either saline or $2 \mathrm{~g} / \mathrm{kg}$ ethanol. After injection, activity monitoring continued for $60 \mathrm{~min}$. The schedule for injection was: day 1-saline, day 2-saline, day 3-ethanol or saline, day 9-saline or ethanol (reversed treatment from day 3 ).

\section{Ethanol-Induced Hypothermia}

At 3 weeks after testing ethanol-induced locomotion, mice were transferred to holding cages $30 \mathrm{~min}$ prior to $2 \mathrm{~g} / \mathrm{kg}$ ethanol administration in a room maintained at ambient temperature. A thermistor probe (TH-5 thermometer, Physitemp) was inserted $1.5 \mathrm{~cm}$ into the rectum, and the temperature reading was recorded immediately before and $10,20,30,40$, and $60 \mathrm{~min}$ after ethanol injection.

\section{Blood Ethanol Concentration}

In a time course study, mice were injected with ethanol 3.5 g/kg i.p. and the tail blood was collected 10, 30, and $90 \mathrm{~min}$ postinjection. At $270 \mathrm{~min}$ postinjection, mice were decapitated and their trunk blood was collected. Whole blood samples $(50-100 \mu \mathrm{l})$ were immediately placed on ice and centrifuged within $30 \mathrm{~min}$ to obtain plasma for further analysis. Plasma ethanol concentration was analyzed in an alcohol oxidation reaction using alcohol dehydrogenase with NAD as a cosubstrate as supplied in a Diagnostics Alcohol Reagent Kit (Sigma). Absorbance at $340 \mathrm{~nm}$ of the reaction product was measured with an Ultraspec 1000 spectrophotometer (Pharmacia). An ethanol standard solution (Sigma) was used to standardize the conversion of absorbance to ethanol concentration. 


\section{Ethanol Two-Bottle Preference Test}

Mice of each genotype were individually housed for 2 weeks. Four control cages (with no mice) were also established at this time to estimate fluid loss from evaporation, dripping, and experimental error. Two bottles (each containing water) were introduced to all cages for 2 days to assess side preferences and basal fluid intake. Bottle spouts had sipper balls to minimize fluid leakage. Ethanol solution was then substituted for water in one bottle; mice first received 3\% ethanol for 4 days, followed by $6 \%$ ethanol for 4 days, followed by $10 \%$ ethanol for 4 days, followed by $20 \%$ ethanol for 4 days. Mice had ad lib access to both bottles throughout the experiment. Both water and ethanol bottles were weighed daily during this time, and within each cage bottles were switched daily to prevent the development of place preference. On days when ethanol concentrations changed, mice were weighed. To assess ethanol intake over a stable baseline, only data from the last 3 days spent at a given ethanol concentration were further analyzed. Changes in ethanol and water weights from control cages were subtracted from the changes determined in subject cages.

\section{Statistics}

Behavioral scores were analyzed for normality using the Shapiro-Wilk's test. One-way or repeated measure ANOVA, followed by Tukey HSD post hoc tests, were used to compare the effect of genotype on normally distributed variables. Genotype comparisons of variables that were not normally distributed were analyzed with the Kruskal-Wallis $H$ test, followed by Tukey HSD post hoc tests. All figures display the mean and standard error of the data to illustrate the central tendency of the variables. For all analyses, significance was assigned at the $p<0.05$ level. Sigma Stat (SPSS) was the statistical software package used for all analyses.

\section{RESULTS}

\section{Generation of $5-\mathrm{HT}_{6} \mathrm{R}$ Null Mutant Mice}

Homologous recombinant ES cell clones were produced with an overall frequency of approximately $6 \%$ of drugresistant colonies (Figure 1b). Blastocyst injections of targeted cells yielded chimeric mice that were bred with C57BL/6J females. Germline transmission of the mutation was confirmed by Southern blot analysis (Figure 1c). To assess the abundance of intact $5-\mathrm{HT}_{6} \mathrm{R}$ mRNA within the brains of mutant mice, Northern blot analysis was performed. Blots were probed with a radiolabeled fragment corresponding to the deleted region of the gene. A $4.2 \mathrm{~kb}$ band was apparent for wild-type, but not mutant samples; an approximate $50 \%$ reduction in the abundance of intact transcript was observed for heterozygotes (Figure 1d). We attempted to confirm loss of protein product via autoradiography using the ligand ${ }^{125} \mathrm{I}-\mathrm{SB} 258585$ (Roberts et al, 2002); however, we were unable to detect specific binding in wild-type brains. This finding is consistent with recent observations indicating that the affinities of ligands used to characterize $5-\mathrm{HT}_{6} \mathrm{Rs}$ in the rat (such as ${ }^{125} \mathrm{I}-\mathrm{SB} 258585$ ) demonstrate reduced affinity for the mouse homolog, and that $5-\mathrm{HT}_{6} \mathrm{R}$ expression levels in the mouse are reduced relative to those in the rat (Hirst et al, 2003).

Heterozygote crosses produced wild-type, heterozygous, and homozygous mutant mice in the expected Mendelian ratios, indicating that the mutation does not impair embryonic or postnatal viability. $5-\mathrm{HT}_{6} \mathrm{R}$ mutant mice were healthy and normal in appearance. No phenotypic differences in body weight were noted across cohorts of male mice (Supplementary Figure S-1). No overt phenotypic abnormalities were noted in brain weight, cytoarchitecture, monoamine levels, serotonin, dopamine, and noradrenergic neuron distribution, or striatal dopamine $D_{1}$ and $D_{2}$ receptor expression (Supplementary Figure S-2).

\section{Absence of Phenotypic Abnormalities of Diverse Baseline Behaviors}

Cohorts of wild-type, heterozygous, and $5-\mathrm{HT}_{6} \mathrm{R}$ mutant mice were assessed for behavioral alterations over multiple domains, including exploratory and anxiety-related behaviors, home cage activity, sensorimotor gating, and cognitive function. There were no genotype-related differences in overall exploratory behavior as measured by distance traveled in an open field (Figure 2a), nor were there any differences in open field anxiety-related behaviors as evaluated by time spent in the field center $v s$ periphery (Figure 2b). Similarly, there was no evidence of an anxietyrelated phenotype in an elevated zero maze (ie no differences in total open quadrant dwell time, number of transitions between open and sheltered maze quadrants, or head dips, Figure $2 \mathrm{c}$ ). Loss of $5-\mathrm{HT}_{6} \mathrm{R}$ function also appeared to have no effect on circadian modulation of locomotor activity. Wild-type, heterozygous, and mutant mice individually housed for 3 days in photobeam activity systems demonstrated no difference in activity onset or offset timing, or in total activity (measured by photobeam breaks, Figure 2d).

Sensorimotor gating was evaluated by prepulse inhibition of acoustic startle responses. Wild-type, heterozygous, and $5-\mathrm{HT}_{6} \mathrm{R}$ mutant mice appropriately demonstrated increased inhibition of a $120 \mathrm{~dB}$ startle stimulus with increasing prepulse magnitudes; however, there were no genotype-related differences in prepulse inhibition (Figure 2e). There were also no phenotypic differences in baseline responses to the $120 \mathrm{~dB}$ startle stimulus (data not shown).

To assay for possible changes in cognitive function, we employed a standard Morris water maze protocol to assess place learning. Three separate experiments were performed and demonstrated no phenotypic differences in acquisition of either the visible or hidden platform tasks (Figure 3a). Similarly, no differences were noted in probe trial performance (performed immediately after the last block of hidden platform trials, Figure 3b). To determine if there were differences in consolidation of long-term spatial memories, one probe trial was performed 28 days after the last day of hidden platform training; again, no performance differences were found between wild-type and mutant mice (Figure 3c). 
a
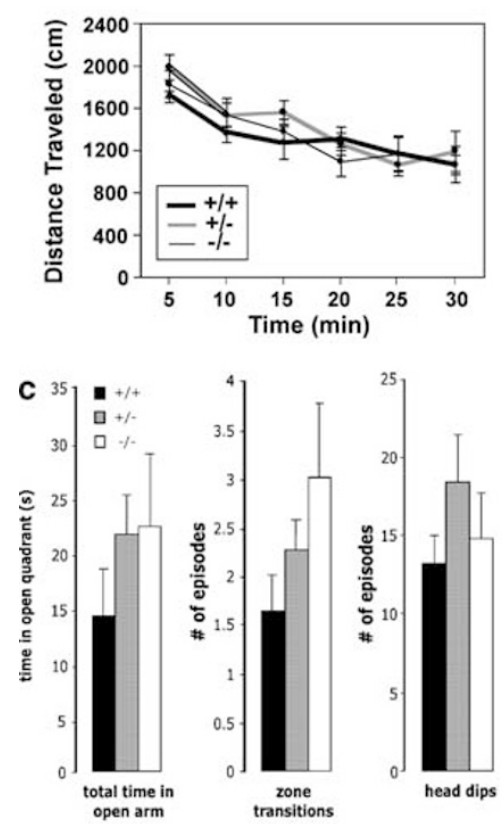

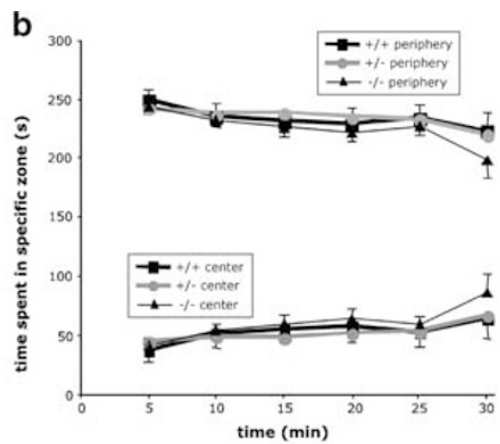

d
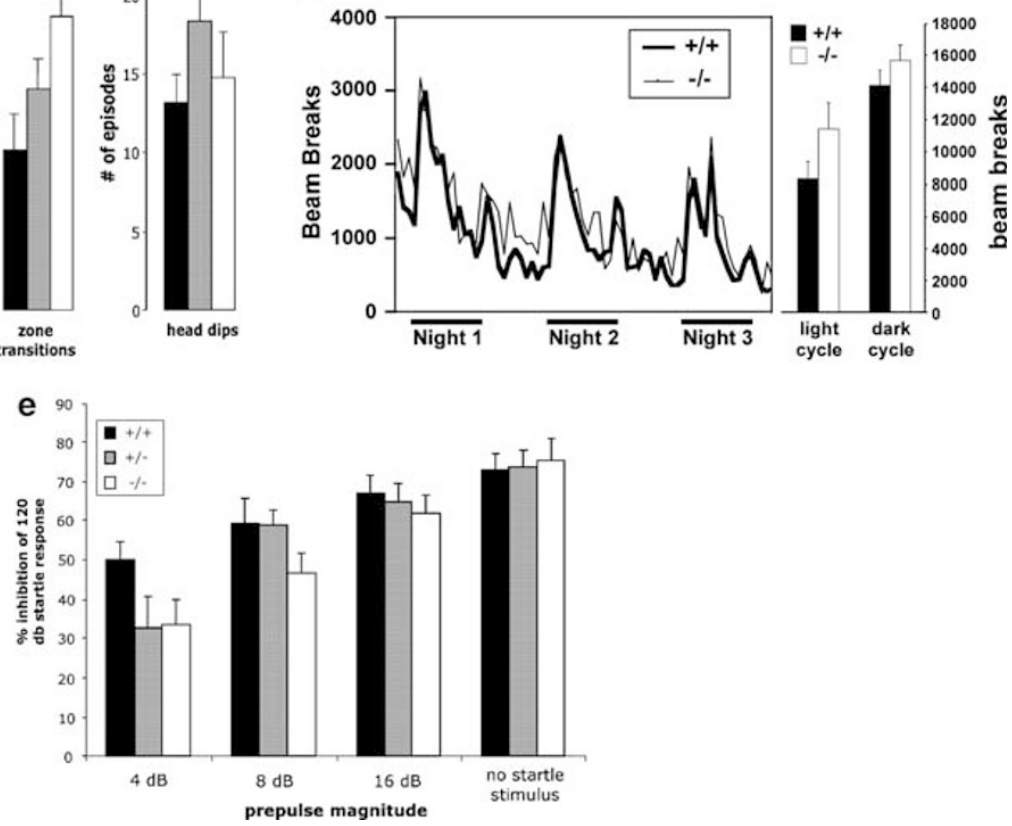

Figure $25-\mathrm{HT}_{6} \mathrm{R}$ mutant mice baseline behavioral screening. (a) No phenotypic differences in overall locomotor distance in a novel environment (over 30 min in the open field test, $F_{2,21}=0.424, p=0.66$ ). (b) No phenotypic differences in open field measures of anxiety-related behaviors. Top group of lines represents total time spent within $7 \mathrm{~cm}$ of open field walls (periphery); bottom group of lines represents total time spent within field center in the same 30 min trials. (c) No phenotypic differences in elevated zero maze measures of anxiety-related behaviors $\left(F_{2,21}=0.816\right.$ (total open arm time), I.755 (zone transitions), 1.027 (head dips), all NS). (d) Similar diurnal patterns of activity in wild-type $(n=9)$ and 5-HT ${ }_{6} \mathrm{R}$ mutant $(n=10)$ mice. Time-of-day had a significant effect on activity, such that animals were more active in the dark phase than in the light phase $\left(F_{1,17}=63.46, p<0.00\right.$ I $)$; however, no phenotypic differences in activity levels or diurnal activity patterns were observed $\left(F_{1.17}=2.144, p=0.161\right)$. Right panel depicts cumulative beam breaks over the second and third days (light cycle, $p<0.14$ Student's t-test) and nights (dark cycle, $p<0.23$, Student's t-test). (e) No differences noted in prepulse inhibition between wild-type $(n=15)$, heterozygous $(n=16)$, and mutant $(n=15)$ mice receiving prepulses 4,8 , and $16 \mathrm{~dB}$ above the baseline $70 \mathrm{~dB}$ prior to a $120 \mathrm{~dB}$ startle stimulus. The rightmost bars are responses within the startle chamber in the absence of a startle stimulus, and represent the maximum prepulse inhibition that may be possible. Repeated measure ANOVA demonstrated a significant effect of stimulus magnitude across all genotypes $\left(F_{3,41}=32.7, p<0.00 \mathrm{I}\right)$, but no significant differences attributable to genotype or a genotype*stimulus interaction. Unless otherwise mentioned, cohort sizes were 8 per genotype, and error bars are \pm I standard error.

\section{Absence of Phenotypic Abnormalities in Responsiveness to Amphetamine and Physostigmine}

Locomotor response to 2 or $10 \mathrm{mg} / \mathrm{kg}$ i.p. amphetamine treatment yielded no phenotypic differences (Supplementary Figure S-3). No phenotypic differences in baseline frequency of stretching or yawning behaviors were noted (data not shown). Similarly, no differences in either stretching or yawning behaviors were appreciated between wild-type, heterozygote, or $5-\mathrm{HT}_{6} \mathrm{R}$ mutant mice following treatment with saline vehicle or the cholinesterase inhibitor physostigmine (Supplementary Figure S-4).

\section{5- $\mathrm{HT}_{6} \mathrm{R}$ Mutant Mice have Decreased Sensitivity to the Ataxic and Sedative Effects of Ethanol}

In an accelerating rotarod assay, all mice showed improved performance following repeated trials, and no phenotypic differences in motor coordination or motor learning were observed (Figure $4 \mathrm{a}$ ). However, $5-\mathrm{HT}_{6} \mathrm{R}$ null mutant mice displayed reduced sensitivity to the ataxic effects of a $2 \mathrm{~g} / \mathrm{kg}$ ethanol injection, remaining on the rotating rod substantially longer than both the wild types and heterozygotes (Figure 4b). A similar trend (that did not reach statistical significance) was noted in mouse rotarod responses after 
$1.5 \mathrm{~g} / \mathrm{kg}$ ethanol injection (Supplementary Figure S-5); by contrast, animals of all genotypes were unable to perform the rotarod assay after $2.5 \mathrm{~g} / \mathrm{kg}$ ethanol injection due to sedation. These findings suggest that $5-\mathrm{HT}_{6} \mathrm{R}$ null mutant mice are less sensitive to the ataxic effects of ethanol. However, since mice in the $2 \mathrm{~g} / \mathrm{kg}$ experimental group had a single $1.5 \mathrm{~g} / \mathrm{kg}$ ethanol injection 4 days before testing, we
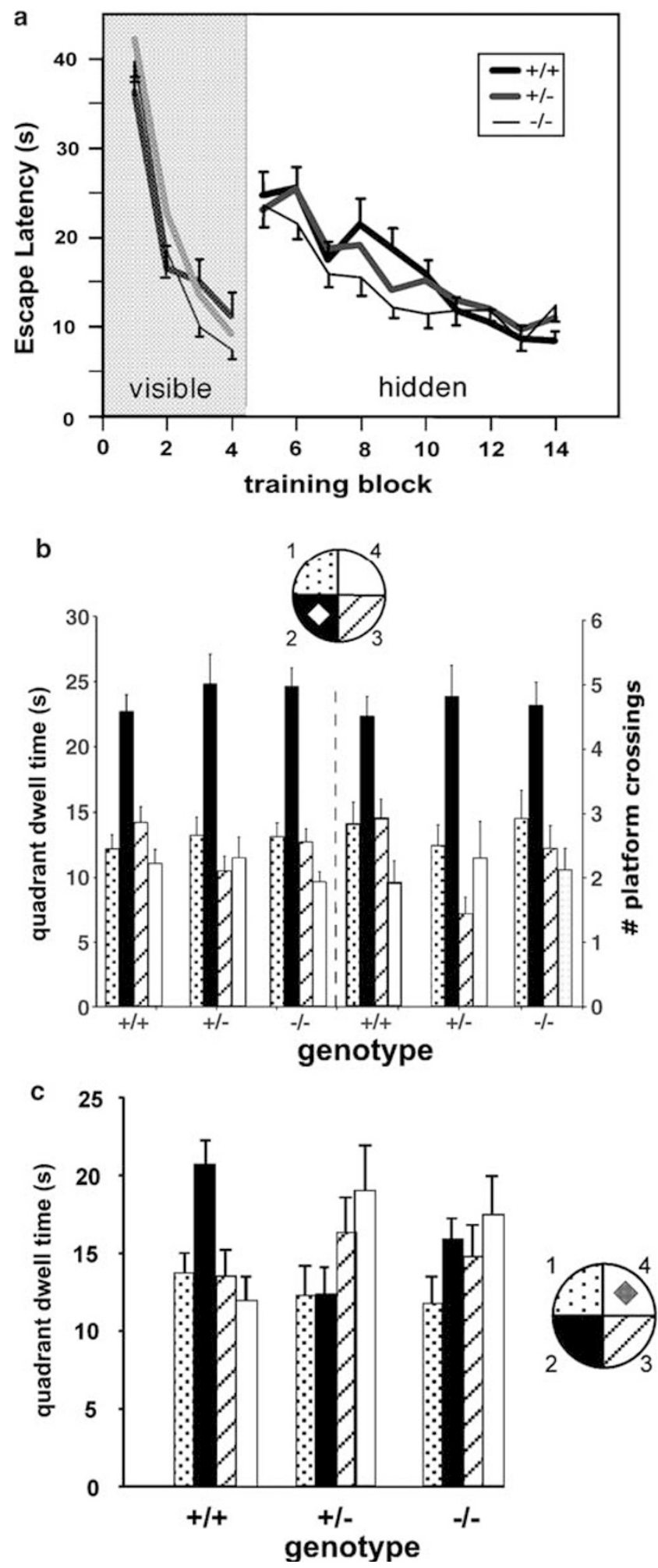

cannot exclude the possibility that phenotypic differences in ethanol tolerance contributed to these results.

$5-\mathrm{HT}_{6} \mathrm{R}$ mutant mice were also more resistant to the sedative effect of ethanol, as tested by LORR. $5-\mathrm{HT}_{6} \mathrm{R}$ mutants regained the righting reflex significantly faster after $3.5 \mathrm{~g} / \mathrm{kg}$ ethanol injection compared to wild-type animals, with heterozygotes exhibiting an intermediate effect (Figure 4c). Mutant mice also displayed increased initial hyperlocomotor responses to ethanol, with increased locomotion in the first $5 \mathrm{~min}$ after $2 \mathrm{~g} / \mathrm{kg}$ ethanol injection (Figure 4d). By contrast, no phenotypic differences were observed in locomotor responses to saline injections (data not shown).

No differences between wild-type and $5-\mathrm{HT}_{6} \mathrm{R}$ mutant mice were noted in ethanol-induced hypothermia following a single $2 \mathrm{~g} / \mathrm{kg}$ ethanol injection (Figure 4e). Thus, the $5-\mathrm{HT}_{6} \mathrm{R}$ mutation may dissociate ethanol-induced ataxic and sedative effects from ethanol-induced hypothermic effects. However, more extensive dose-response studies would be required to definitively exclude the possibility that the $5-\mathrm{HT}_{6} \mathrm{R}$ mutation alters hypothermic responses to ethanol. Assays of blood ethanol concentration following a single $3.5 \mathrm{~g} / \mathrm{kg}$ ethanol injection detected no differences in ethanol metabolism between wild-type and $5-\mathrm{HT}_{6} \mathrm{R}$ mutant mice (Figure 4f).

\section{No Differences in Two-Bottle Ethanol Preference Between Wild-type and 5- $\mathrm{HT}_{6} \mathrm{R}$ Mutant Mice}

In light of phenotypic differences in acute responses to ethanol, we examined ethanol preference in these mice. Figure 5 depicts the results of a two-bottle preference test, a simple behavioral assay for altered ethanol ingestion between wild-type and $5-\mathrm{HT}_{6} \mathrm{R}$ mutant mice. No differences were noted in either ethanol ingestion (Figure 5a) or ethanol preference ratio (ethanol solution consumed/total fluid intake; Figure $5 \mathrm{~b}$ ) between wild-type and $5-\mathrm{HT}_{6} \mathrm{R}$ mutant mice.

\section{DISCUSSION}

We have presented initial analyses of mice bearing a constitutive null mutation of the $5-\mathrm{HT}_{6}$ receptor. Although these animals perform normally in a wide variety of standard behavioral assays, they exhibit abnormal responses to ethanol. These mice are less sensitive to the acute ataxic and sedative effects of ethanol as measured in rotarod and loss-of-righting-reflex assays; they also display

Figure $35-\mathrm{HT}_{6} \mathrm{R}$ mutant mice cognitive testing. (a) No phenotypic differences were noted in escape latencies during the visible or hidden platform tasks of the Morris water maze ( $n=24$ wild type, 16 heterozygous, 24 mutant, $F_{2,59}=1.417$ for genotype effect (NS), $F_{\mid 8,531}=0.211$ for genotype*block interaction (NS)). Mice trained to quadrant 2. (b) No phenotypic differences in probe trial performance (training responses shown in panel a) were noted. Leftmost bars represent quadrant dwell times, rightmost bars represent platform crossings, all mice trained to quadrant 2. (c) No phenotypic differences in 28-day delayed probe trial performance as measured by time spent in trained quadrant (cohorts of eight per genotype, one-way ANOVA, primary factor genotype, $F_{2,19}=2.2378, p<0.1341$ ). Mice trained to quadrant 4. Error bars are \pm I standard error. 

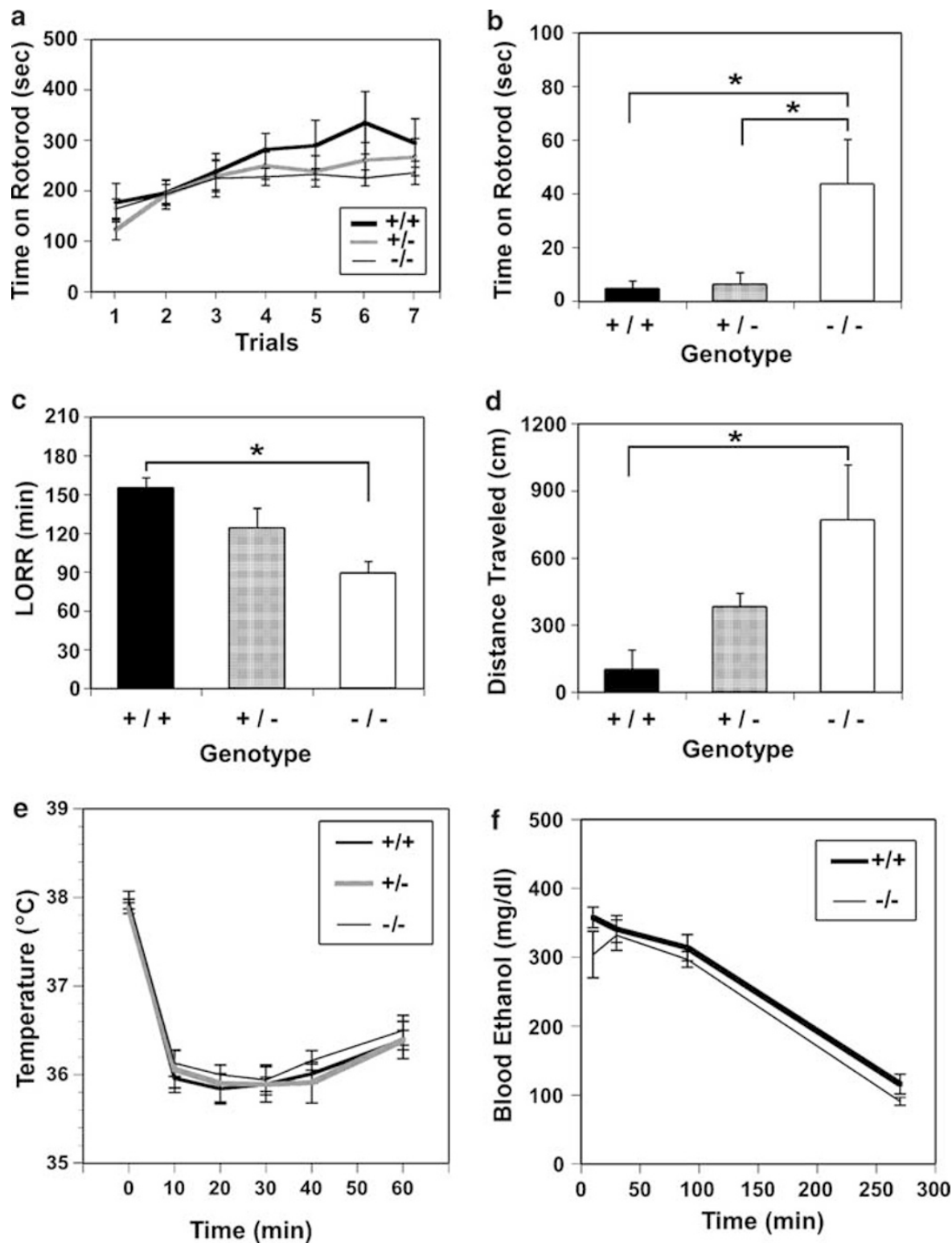

Figure 4 Altered acute ethanol responses in 5- $\mathrm{HT}_{6} \mathrm{R}$ mutant mice. (a) No differences in baseline rotarod performance between wild-type, heterozygous, and mutant mice over the seventh training sessions. Performance at the end of the seventh trial session was improved relative to initial performance for all groups $\left(F_{6,96}=10.38, p<0.001\right.$ for time, $F_{2,16}=0.486, p=0.624$ for genotype). (b) Following $2 \mathrm{~g} / \mathrm{kg}$ ethanol administration, $5-\mathrm{HT}_{6} \mathrm{R}$ mutant mice remained on the rotarod significantly longer than both heterozygote and wild-type mice $\left(F_{2,23}=4.753, p<0.05\right)$. (c) Following $3.5 \mathrm{~g} / \mathrm{kg}$ ethanol administration, $5-\mathrm{HT}{ }_{6} \mathrm{R}$ mutant mice regained their righting reflex more rapidly than either heterozygous or wild-type mice $\left(F_{223}=8.45 \mathrm{I}, p<0.005\right)$. ( $\left.d\right) 5$ - $\mathrm{HT} \mathrm{T}_{6} \mathrm{R}$ mice show increased sensitivity to ethanol-induced locomotor hyperactivity effects in the initial $5 \mathrm{~min}$ after $2 \mathrm{~g} / \mathrm{kg}$ ethanol $\left(F_{2,23}=4.59 \mathrm{l}, p<0.05\right)$ administration. (e) No phenotypic differences in ethanol-induced $\left(2 \mathrm{~g} / \mathrm{kg}\right.$ ) hypothermia $\left(F_{221}=0.31, p=0.737\right)$ were observed. ( $f$ ) No differences in blood ethanol concentration $\left(F_{1,14}=1.518, p=0.238\right)$ were observed between wild-type and $5-H_{6} T_{6}$ mutant mice. Cohort sizes were eight per genotype; error bars are \pm 1 standard error. Asterisks denote relationships whose statistical significance were $p<0.05$.

increased locomotion immediately following ethanol administration. These findings represent the initial indication that $5 \mathrm{HT}_{6} \mathrm{Rs}$ contribute to serotonergic influences on ethanol responses.

\section{5-HT ${ }_{6} \mathrm{R}$-Influenced Behaviors}

Initial studies that demonstrated high binding affinities of atypical antipsychotic agents such as clozapine at $5-\mathrm{HT}_{6} \mathrm{Rs}$ (Roth et al, 1994) raised the possibility that this receptor influences sensorimotor gating and/or psychotic processes.
Some studies indicated that $5-\mathrm{HT}_{6} \mathrm{R}$ antisense oligonucleotides (Bourson et al, 1995; Sleight et al, 1996) or 5- $\mathrm{HT}_{6} \mathrm{R}$ antagonists (Unsworth and Molinoff, 1994; Sleight et al, 1998; Bentley et al, 1999; Routledge et al, 1999) produced yawning-stretching behaviors that could be blocked by the muscarinic cholinergic antagonist atropine or potentiated by the cholinesterase inhibitor physostigmine. Other studies have implicated $5-\mathrm{HT}_{6} \mathrm{Rs}$ in the modulation of cognitive processes (Russell and Dias, 2002). However, studies of the roles of $5-\mathrm{HT}_{6} \mathrm{Rs}$ in these and other behavioral processes have produced conflicting results. 

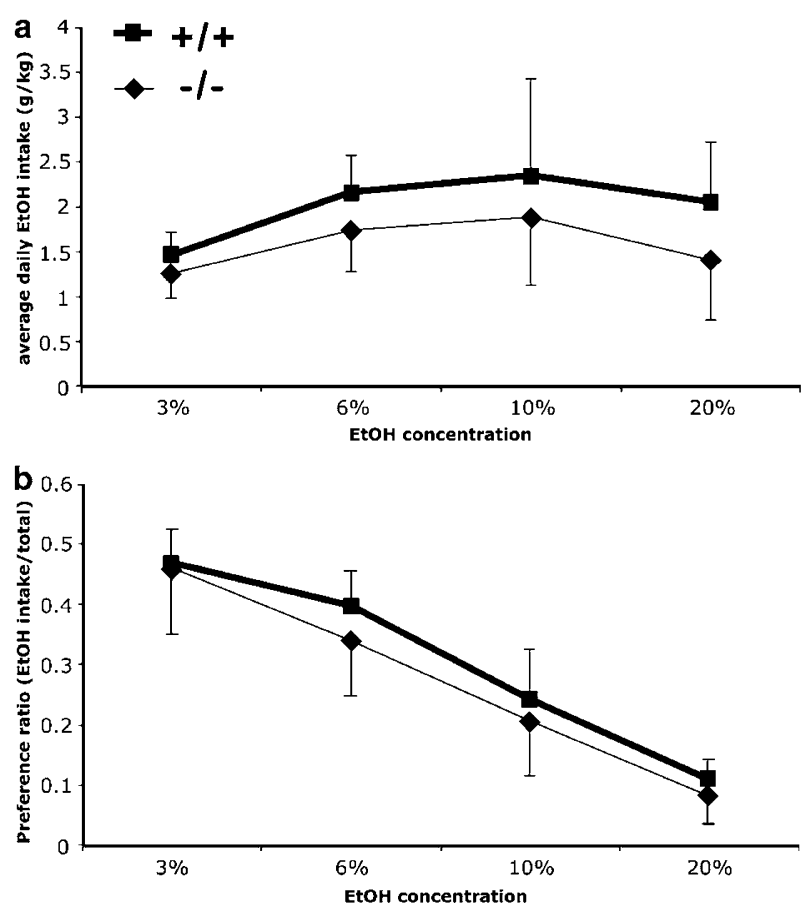

Figure 5 No differences in total ethanol intake $\left(a, F_{3,15}=0.47\right.$, $p=0.503)$ or ethanol preference $\left(b, F_{3,15}=0.25, p=0.624\right)$ were noted between wild-type and $5-\mathrm{HT}_{6} \mathrm{R}$ mutant mice. Ethanol concentration had a significant effect on ethanol preference in both wild-type and $5-\mathrm{HT}_{6} \mathrm{R}$ mutant mice $\left(b, F_{3,15}=8.00, p=0.004\right)$. Cohort sizes were eight per genotype; error bars are \pm I standard error.

With regard to cognition, rats acutely treated with $5-\mathrm{HT}_{6} \mathrm{R}$ antagonists demonstrated improved spatial memory retention 1 week after Morris maze training (Woolley et al, 2001; Stean et al, 2002). 5- $\mathrm{HT}_{6} \mathrm{R}$ antagonists also enhanced acquisition and reversed a scopolamine-evoked deficit in rat operant autoshaping and passive avoidance tasks (Bos et al, 2001; Meneses, 2001; Riemer et al, 2003). Pretreatment with a $5-\mathrm{HT}_{6} \mathrm{R}$ antagonist also improved rat performance of an attentional set-shifting task, a rodent analog of the Wisconsin card sorting test, a commonly used assay of cognitive-guided sorting (Hatcher et al, 2005). However, other investigators have been unable to demonstrate $5-\mathrm{HT}_{6} \mathrm{R}$-induced enhancements of cognitive function (Russell and Dias, 2002; Lindner et al, 2003). In three different cohorts, we were unable to demonstrate phenotypic differences in either Morris water maze acquisition or probe trial performance.

Similar uncertainty exists regarding the relationship between $5-\mathrm{HT}_{6} \mathrm{Rs}$ and anxiety-related behaviors. In rats, continuous intraventricular infusion of $5-\mathrm{HT}_{6} \mathrm{R}$ antisense oligonucleotides evoked increased anxiety-related behaviors on an elevated plus maze and a social interaction test (Hamon et al, 1999; Otano et al, 1999). However, similar treatments failed to alter conditioned freezing responses in rats (Yoshioka et al, 1998). We have been unable to detect a significant anxiety-related phenotype in $5-\mathrm{HT}_{6} \mathrm{R}$ null mutant mice.

Few studies have investigated how $5-\mathrm{HT}_{6} \mathrm{Rs}$ may modulate responses to substances of abuse. Rats pretreated with the selective $5-\mathrm{HT}_{6} \mathrm{R}$ antagonist SB 258510A demonstrated enhanced locomotor responses to amphetamine treatment that were accompanied by increased extracellular dopamine efflux in the prefrontal cortex (Frantz et al, 2002). However, this effect was not observed in response to cocaine administration (Frantz et al, 2002). We were unable to demonstrate differences in locomotor sensitivity to either low- or high-dose amphetamine treatment between wildtype and $5-\mathrm{HT}_{6} \mathrm{R}$ mutant mice. However, a more extensive dose-response study would be required to definitively exclude the possibility that the mutation alters sensitivity to amphetamine at other doses not tested in these animals.

To obtain a more complete behavioral profile of the 5$\mathrm{HT}_{6} \mathrm{R}$ mutant mice, we further surveyed a number of baseline behaviors, including circadian rhythms of locomotor activity, exploration in a novel open field, motor coordination, and sensorimotor gating. We were unable to detect any phenotypic differences in these behaviors, nor in the stretching and yawning behaviors proposed to be influenced by $5-\mathrm{HT}_{6} \mathrm{Rs}$. Thus, initial behavioral assessment of $5-\mathrm{HT}_{6} \mathrm{R}$ mutant mice demonstrated no significant differences across a wide variety of behavioral domains.

There are several possible explanations for why we were unable to detect differences in behaviors postulated to have $5-\mathrm{HT}_{6} \mathrm{R}$-mediated influences. 5- $\mathrm{HT}_{6} \mathrm{R}$-evoked phenotypes in yawning-stretching, cognitive performance, and anxietyrelated behaviors have not been consistently demonstrated in rats (Woolley et al, 2004). Moreover, constitutive deletion of the $5-\mathrm{HT}_{6} \mathrm{R}$ may evoke developmental compensations masking these phenotypes; similarly, changes in behavior resulting from chronic $5-\mathrm{HT}_{6} \mathrm{R}$ deletion may differ from those induced by acute pharmacological or antisense oligonucleotide treatment. Additionally, species differences in $5-\mathrm{HT}_{6} \mathrm{R}$ mRNA expression may contribute to species differences in behaviors sensitive to $5-\mathrm{HT}_{6} \mathrm{R}$ function. Recent evidence indicates that differences between mouse and rat/human $5-\mathrm{HT}_{6} \mathrm{R}$ receptor sequences are associated with differences in their affinities for $5-\mathrm{HT}_{6} \mathrm{R}$ antagonist compounds, while not altering binding affinities for serotonin (Hirst et al, 2003).

\section{5- $\mathrm{HT}_{6}$ Receptors Influence Acute Responses to Ethanol Consumption}

Whereas abundant evidence implicates central serotonin systems in responses to ethanol, the relative contributions provided by particular serotonin receptor subtypes remain unclear. The enrichment of $5-\mathrm{HT}_{6} \mathrm{R}$ expression in striatal regions implicated in ethanol responses raised the possibility that these receptors may play a role in these responses. Here, we report that $5-\mathrm{HT}_{6} \mathrm{Rs}$ influence acute responses to ethanol administration.

Following a moderate dose of ethanol, 5- $\mathrm{HT}_{6} \mathrm{R}$ mutant mice remained on a rotating rod for a longer duration compared with wild-type mice; similarly, $5-\mathrm{HT}_{6} \mathrm{R}$ mutant mice recovered their righting reflex more rapidly than wild types. These findings suggest that $5-\mathrm{HT}_{6} \mathrm{R}$ mutant mice are less sensitive to the acute ataxic and sedative effects of ethanol. $5-\mathrm{HT}_{6} \mathrm{R}$ mutant mice also displayed increased locomotor activity levels following low-dose ethanol administration. Hyperlocomotion following low-dose ethanol administration is a well-studied phenomenon (Phillips and Shen, 1996); in C57BL/6 mice, this effect is most prominent 
in the first $5 \mathrm{~min}$ following administration (Crabbe et al, 1982). This finding suggests that the mutation enhances locomotor activation and/or reduces behavioral sedation in response to low-dose ethanol. In our experimental design, mice treated with $2 \mathrm{~g} / \mathrm{kg}$ ethanol in the ataxia test received a single $1.5 \mathrm{~g} / \mathrm{kg}$ ethanol injection 4 days prior to testing. Therefore, we cannot completely rule out whether ethanol tolerance contributed to our findings. However, $5-\mathrm{HT}_{6} \mathrm{R}$ mutant mice receiving an initial $1.5 \mathrm{~g} / \mathrm{kg}$ ethanol injection did show a trend, albeit not statistically significant, toward decreased ethanol-induced ataxia. The above findings are also not explained by differences in ethanol clearance.

Since ethanol can induce significant hypothermia, which in turn might influence coordination and locomotion, we specifically tested ethanol-induced hypothermia at the dose $(2 \mathrm{~g} / \mathrm{kg})$ where these behaviors differed significantly between $5-\mathrm{HT}_{6} \mathrm{R}$ mutant and wild-type mice. However, we did not identify any phenotypic differences in ethanolinduced hypothermia at this dose. This finding does not preclude the possibility that phenotypic differences in ethanol-induced hypothermia may occur at other ethanol doses.

Although no phenotypic differences were observed in a standard two-bottle intake test, several factors preclude us from concluding that $5-\mathrm{HT}_{6} \mathrm{Rs}$ do not influence ethanol selfadministration. Ethanol ingestion was less than anticipated for C57BL/6 or C57BL/6-129 mixed genetic background mice (Belknap et al, 1993; Mihalek et al, 2001; Thiele et al, 2000); a floor effect may potentially mask genotypic differences. Furthermore, the mixed genetic background of these mice could obscure the impact of the $5-\mathrm{HT}_{6} \mathrm{R}$ mutation. In addition, differences in circadian patterns of ethanol ingestion (Gill et al, 1986) cannot be discerned by a two-bottle preference test. In future work, it will be of interest to test mice congenic for the $5-\mathrm{HT}_{6} \mathrm{R}$ mutation using operant assays that estimate the reinforcing properties of ethanol while eliciting levels of intake that produce pharmacological effects on physiology and behavior (Cunningham et al, 2000; Risinger et al, 1998; Roberts et al, 1999; Samson et al, 1998).

\section{Serotonin Systems and Ethanol Responses}

Abundant evidence indicates that serotonergic systems influence both ethanol intake and ethanol responses. Human alcoholism syndromes have been subdivided into distinct subcategories associated with alterations in central serotonergic function (Virkkunen and Linnoila, 1996; Higley and Linnoila, 1997) and serotonin transporter promoter polymorphisms (Hallikainen et al, 1999). Evidence exists that specific subgroups of alcoholics decrease their ethanol ingestion following selective serotonin reuptake inhibitor (SSRI) therapy (Naranjo and Knoke, 2001; Pettinati, 2001). In animal studies, lines of rats bred for increased ethanol preference demonstrate decreased serotonergic immunoreactivity within the median and dorsal raphé nucleus (Zhou et al, 1994) and localized reductions in telencephalon serotonin content and innervation (Murphy et al, 1987, 2002; Gongwer et al, 1989; Zhou et al, 1991; Myers et al, 1998; Lucas and McMillen, 2002). Firing rates of dorsal raphé neurons decrease following acute ethanol administration (Pistis et al, 1997).
Although our results suggest that $5-\mathrm{HT}_{6} \mathrm{Rs}$ contribute to the serotonergic modulation of ethanol responses, previous studies have also defined roles for other components of serotonergic neurotransmission. Some lines of mice carrying a constitutive $5-\mathrm{HT}_{1 \mathrm{~B}}$ receptor mutation demonstrate increased ethanol consumption compared to wild types (Crabbe et al, 1996; Phillips et al, 1999; however, see Risinger et al, 1999; Bouwknecht et al, 2000; Gorwood et al, 2002 for conflicting reports). Other serotonin receptors, including $5-\mathrm{HT}_{3} \mathrm{R}$ (Engel et al, 1998; Engel and Allan, 1999; Rodd-Henricks et al, 2003), 5- $\mathrm{HT}_{2 \mathrm{~A}} \mathrm{R}$ (West et al, 1998; Maurel et al, 1999; however, see Wilson et al, 2000; Blakley et al, 2001 for conflicting reports), and $5-\mathrm{HT}_{2 \mathrm{C}} \mathrm{R}$ (Maurel et al, 1999; Tomkins et al, 2002) also modulate ethanol ingestion. Finally, multiple lines of evidence demonstrate that SSRIs affect multiple responses to ethanol ingestion, including overall ethanol ingestion, taste aversion, and ethanol discrimination (Gulley et al, 1995; Gardell et al, 1997; Risinger, 1997; Lamb and Jarbe, 2001).

The precise mechanisms through which loss of $5-\mathrm{HT}_{6} \mathrm{R}$ function leads to increased ethanol resistance are unclear. A large body of literature suggests that the striatum and nucleus accumbens are important loci for the locomotor and behavioral effects of ethanol ingestion (Weiss and Porrino, 2002). Acute ethanol administration evokes serotonin release in the nucleus accumbens (Yoshimoto et al, 1992; Yan, 1999). 5- $\mathrm{HT}_{6} \mathrm{Rs}$ within the striatum and nucleus accumbens may thus contribute to part of the serotonergic response to ethanol ingestion, and their absence may reduce an aspect of this response.

In summary, we have identified a role for $5 \mathrm{HT}_{6} \mathrm{Rs}$ in modulating the ataxic and sedative effects of ethanol in the mouse. This phenotype was not secondary to changes in ethanol pharmacokinetics. Furthermore, particular ethanolrelated responses were differentially affected by the mutation, since there were no observed phenotypic effects on ethanol clearance or in ethanol-evoked hypothermia. Our data suggest a specific ethanol phenotype in $5-\mathrm{HT}_{6} \mathrm{R}$ mutant mice, and indicate that $5-\mathrm{HT}_{6} \mathrm{Rs}$ influence behavioral responses to ethanol.

\section{ACKNOWLEDGEMENTS}

This research was funded in part by grants from the American Federation for Aging Research (SJB), Department of Veteran's Affairs (HMC), National Alliance for Research on Schizophrenia and Depression (HMC), and Program for Minority Research Training in Psychiatry 5T32MH19126 (HMC). We thank Drs Mark Hamblin and Ruth Kohen for a $5-\mathrm{HT}_{6}$ receptor genomic fragment, Dr Roger Pederson for 129-derived embryonic stem cells, and Dr Warren Hirst for use of ${ }^{125} \mathrm{I}-\mathrm{SB} 258585$. We also thank Jean Danao, Irene Yun, Aileen Sweeney, and Jed Holtzman for their technical skills and support.

\section{REFERENCES}

Aghajanian GK, Sanders-Bush E (2002). Serotonin. In: Davis KL, Charney D, Coyle J, Nemeroff C (eds). Neuropsychopharmacology: The Fifth Generation of Progress. American College of Neuropsychopharmacology: Nashville, TN. pp 15-34. 
Barnes NM, Sharp T (1999). A review of central 5-HT receptors and their function. Neuropharmacology 38: 1083-1152.

Belknap JK, Crabbe JC, Young ER (1993). Voluntary consumption of ethanol in 15 inbred mouse strains. Psychopharmacology (Berl) 112: 503-510.

Bentley JC, Bourson A, Boess FG, Fone KC, Marsden CA, Petit N et al (1999). Investigation of stretching behaviour induced by the selective $5-\mathrm{HT}_{6}$ receptor antagonist, Ro 04-6790, in rats. $\mathrm{Br} J$ Pharmacol 126: 1537-1542.

Blakley GG, Pohorecky LA, Benjamin D (2001). Bidirectional changes in ethanol consumption in rats with site-specific antisense down-regulation of 5-hydroxytryptamine $2 \mathrm{~A}$ receptors in brain. J Pharmacol Exp Ther 299: 277-289.

Boess FG, Riemer C, Bos M, Bentley J, Bourson A, Sleight AJ (1998). The $5-\mathrm{HT}_{6}$ receptor selective radioligand $\left[{ }^{3} \mathrm{H}\right]$ Ro 63-0563 labels 5-hydroxytryptamine receptor binding sites in rat and porcine striatum. Mol Pharmacol 54: 577-583.

Bos M, Sleight AJ, Godel T, Martin JR, Riemer C, Stadler H (2001). 5 -HT(6) receptor antagonists: lead optimisation and biological evaluation of $\mathrm{N}$-aryl and $\mathrm{N}$-heteroaryl 4 -amino-benzene sulfonamides. Eur J Med Chem 36: 165-178.

Bourson A, Borroni E, Austin RH, Monsma Jr FJ, Sleight AJ (1995). Determination of the role of the $5-\mathrm{HT}_{6}$ receptor in the rat brain: a study using antisense oligonucleotides. J Pharmacol Exp Ther 274: 173-180.

Bouwknecht JA, Hijzen TH, van der Gugten J, Maes RA, Hen R, Olivier B (2000). Ethanol intake is not elevated in male 5-HT(1B) receptor knockout mice. Eur J Pharmacol 403: 95-98.

Branchek TA, Blackburn TP (2000). 5- $\mathrm{HT}_{6}$ receptors as emerging targets for drug discovery. Annu Rev Pharmacol Toxicol 40: 319-334.

Crabbe JC, Johnson NA, Gray DK, Kosobud A, Young ER (1982). Biphasic effects of ethanol on open-field activity: sensitivity and tolerance in $\mathrm{C} 57 \mathrm{BL} / 6 \mathrm{~N}$ and $\mathrm{DBA} / 2 \mathrm{~N}$ mice. J Comp Physiol Psychol 96: 440-451.

Crabbe JC, Phillips TJ, Feller DJ, Hen R, Wenger CD, Lessov CN et al (1996). Elevated alcohol consumption in null mutant mice lacking 5- $\mathrm{HT}_{1 \mathrm{~B}}$ serotonin receptors. Nat Genet 14: 98-101.

Cunningham CL, Fidler TL, Hill KG (2000). Animal models of alcohol's motivational effects. Alcohol Res Health 24: 85-92.

Engel SR, Allan AM (1999). 5- $\mathrm{HT}_{3}$ receptor over-expression enhances ethanol sensitivity in mice. Psychopharmacology (Berl) 144: 411-415.

Engel SR, Lyons CR, Allan AM (1998). 5- $\mathrm{HT}_{3}$ receptor overexpression decreases ethanol self administration in transgenic mice. Psychopharmacology (Berl) 140: 243-248.

Frantz KJ, Hansson KJ, Stouffer DG, Parsons LH (2002). 5- $\mathrm{HT}_{6}$ receptor antagonism potentiates the behavioral \& neurochemical effects of amphetamine but not cocaine. Neuropharmacology 44: 170-180.

Gardell LR, Whalen CA, Chattophadyay S, Cavallaro CA, Hubbell CL, Reid LD (1997). Combination of naltrexone and fluoxetine on rats' propensity to take alcoholic beverage. Alcohol Clin Exp Res 21: 1435-1439.

Gérard C, Martres M-P, Lefèvre K, Miquel MC, Vergé D, Lanfumey $\mathrm{L}$ et al (1997). Immuno-localization of serotonin $5-\mathrm{HT}_{6}$ receptorlike material in the rat central nervous system. Brain Res 746: 207-219.

Gill K, France C, Amit Z (1986). Voluntary ethanol consumption in rats: an examination of blood/brain ethanol levels and behavior. Alcohol Clin Exp Res 10: 457-462.

Glatt CE, Snowman AM, Sibley DR, Snyder SH (1995). Clozapine: selective labeling of sites resembling $5 \mathrm{HT}_{6}$ serotonin receptors may reflect psychoactive profile. Mol Med 1: 398-406.

Gongwer MA, Murphy JM, McBride WJ, Lumeng L, Li TK (1989). Regional brain contents of serotonin, dopamine and their metabolites in the selectively bred high- and low-alcohol drinking lines of rats. Alcohol 6: 317-320.
Gorwood P, Aissi F, Batel P, Ades J, Cohen-Salmon C, Hamon M et al (2002). Reappraisal of the serotonin 5-HT(1B) receptor gene in alcoholism: of mice and men. Brain Res Bull 57: 103-107.

Gulley JM, McNamara C, Barbera TJ, Ritz MC, George FR (1995). Selective serotonin reuptake inhibitors: effects of chronic treatment on ethanol-reinforced behavior in mice. Alcohol 12: 177-181.

Hallikainen T, Saito T, Lachman HM, Volavka J, Pohjalainen T, Ryynanen OP et al (1999). Association between low activity serotonin transporter promoter genotype and early onset alcoholism with habitual impulsive violent behavior. $\mathrm{Mol}$ Psychiatry 4: 385-388.

Hamon M, Doucet E, Lefevre K, Miquel MC, Lanfumey L, Insausti $\mathrm{R}$ et al (1999). Antibodies and antisense oligonucleotide for probing the distribution and putative functions of central $5-\mathrm{HT}_{6}$ receptors. Neuropsychopharmacology 21: 68S-76S.

Hatcher PD, Brown VJ, Tait DS, Bate S, Overend P, Hagan JJ et al (2005). 5- $\mathrm{HT}_{6} \mathrm{R}$ antagonists improve performance in an attentional set shifting task in rats. Psychopharmacol 181: 253-259.

Heisler LK, Chu H-M, Brennan TJ, Danao JA, Bajwa P, Parsons LH et al (1998). Elevated anxiety and antidepressant-like responses in serotonin 5- $\mathrm{HT}_{1 \mathrm{~A}}$ receptor mutant mice. Proc Natl Acad Sci USA 95: 15049-15054.

Higley JD, Linnoila M (1997). A nonhuman primate model of excessive alcohol intake: personality and neurobiological parallels of type I- and type II-like alcoholism. In: Galanter M (ed). Recent Developments in Alcoholism, Vol 1. Plenum Press: New York. pp 191-219.

Hirst WD, Abrahamsen B, Blaney FE, Calver AR, Aloj L, Price GW et al (2003). Differences in the central nervous system distribution and pharmacology of the mouse 5-hydroxytryptamine-6 receptor compared with rat and human receptors investigated by radioligand binding, site-directed mutagenesis, and molecular modeling. Mol Pharmacol 64: 1295-1308.

Hoyer D, Clarke DE, Fozard JR, Hartig PR, Martin GR, Mylecharane EJ et al (1994). International Union of Pharmacology classification of receptors for 5-hydroxytryptamine (serotonin). Pharmacol Rev 46: 157-203.

Kohen R, Metcalf MA, Khan N, Druck T, Huebner K, Lachowicz JE et al (1996). Cloning, characterization, and chromosomal localization of a human $5-\mathrm{HT}_{6}$ serotonin receptor. J Neurochem 66: 47-56.

Lamb RJ, Jarbe TU (2001). Effects of fluvoxamine on ethanol-reinforced behavior in the rat. J Pharmacol Exp Ther 297: 1001-1009.

Lane H-Y, Lin C-C, Huang C-H, Chang Y-C, Hsu S-K, Chang W-H (2004). Risperidone response and $5-\mathrm{HT}_{6}$ receptor gene variance; genetic association analysis with adjustment for nongenetic confounders. Schizophr Res 67: 63-70.

Lindner MD, Hodges Jr DB, Hogan JB, Orie AF, Corsa JA, Barten DM et al (2003). An assessment of the effects of serotonin $6\left(5-\mathrm{HT}_{6}\right)$ receptor antagonists in rodent models of learning. J Pharmacol Exp Ther 307: 682-691.

Lucas LA, McMillen BA (2002). Differences in brain area concentrations of dopamine and serotonin in Myers' High Ethanol Preferring (mHEP) and outbred rats. J Neural Transm 109: 279-292.

Mansour SL, Thomas KR, Capecchi MR (1988). Disruption of the proto-oncogene int-2 in mouse embryo-derived stem cells: a general strategy for targeting mutations to non-selectable genes. Nature 336: 348-352.

Maurel S, De Vry J, De Beun R, Schreiber R (1999). 5- $\mathrm{HT}_{2 \mathrm{~A}}$ and $5-\mathrm{HT}_{2 \mathrm{C}} / 5-\mathrm{HT}_{1 \mathrm{~B}}$ receptors are differentially involved in alcohol preference and consummatory behavior in cAA rats. Pharmacol Biochem Behav 62: 89-96.

Meneses A (2001). Role of 5- $\mathrm{HT}_{6}$ receptors in memory formation. Drug News Perspect 14: 396-400. 
Mihalek RM, Bowers BJ, Wehner JM, Kralic JE, VanDoren MJ, Morrow $\mathrm{AL}$ et al (2001). $\mathrm{GABA}_{\mathrm{A}}$-receptor $\delta$ subunit knockout mice have multiple defects in behavioral responses to ethanol. Alcohol Clin Exp Res 25: 1708-1718.

Monsma Jr FJ, Shen Y, Ward RP, Hamblin MW, Sibley DR (1993). Cloning and expression of a novel serotonin receptor with high affinity for tricyclic psychotropic drugs. Mol Pharmacol 43: 320-327.

Murphy JM, McBride WJ, Lumeng L, Li TK (1987). Contents of monoamines in forebrain regions of alcohol-preferring $(\mathrm{P})$ and -nonpreferring (NP) lines of rats. Pharmacol Biochem Behav 26: 389-392.

Murphy JM, Stewart RB, Bell RL, Badia-Elder NE, Carr LG, McBride WJ et al (2002). Phenotypic and genotypic characterization of the Indiana University rat lines selectively bred for high and low alcohol preference. Behav Genet 32: 363-388.

Myers RD, Robinson DE, West MW, Biggs TA, McMillen BA (1998). Genetics of alcoholism: rapid development of a new highethanol-preferring (HEP) strain of female and male rats. Alcohol 16: 343-357.

Naranjo CA, Knoke DM (2001). The role of selective serotonin reuptake inhibitors in reducing alcohol consumption. J Clin Psychiatry 62(Suppl 20): 18-25.

Ohmori O, Shinkai T, Hori H, Nakamura J (2001). Novel polymorphism in the $5^{\prime}$-upstream region of the human $5-\mathrm{HT}_{6}$ receptor gene and schizophrenia. Neurosci Lett 310: 17-20.

Otano A, Frechilla D, Cobreros A, Cruz-Orive LM, Insausti A, Insausti $\mathrm{R}$ et al (1999). Anxiogenic-like effects and reduced stereological counting of immunolabelled 5 hydroxytryptamine 6 receptors in rat nucleus accumbens by antisense oligonucleotides. Neuroscience 92: 1001-1009.

Pettinati HM (2001). The use of selective serotonin reuptake inhibitors in treating alcoholic subtypes. J Clin Psychiatry 62(Suppl 20): 26-31.

Phillips TJ, Hen R, Crabbe JC (1999). Complications associated with genetic background effects in research using knockout mice. Psychopharmacology (Berl) 147: 5-7.

Phillips TJ, Shen EH (1996). Neurochemical bases of locomotion and ethanol stimulant effects. Int Rev Neurobiol 39: 243-282.

Pistis M, Muntoni AL, Gessa G, Diana M (1997). Effects of acute, chronic ethanol and withdrawal on dorsal raphe neurons: electrophysiological studies. Neuroscience 79: 171-176.

Riemer C, Borroni E, Levet-Trafit B, Martin JR, Poli S, Porter RH et al (2003). Influence of the $5-\mathrm{HT}_{6}$ receptor on acetylcholine release in the cortex: pharmacological characterization of 4-(2bromo-6-pyrrolidin-1-ylpyridine-4-sulfonyl)phenylamine, a potent and selective $5-\mathrm{HT}_{6}$ receptor antagonist. $\mathrm{J}$ Med Chem 46: 1273-1276.

Risinger FO (1997). Fluoxetine's effects on ethanol's rewarding, aversive and stimulus properties. Life Sci 61: PL235-PL242.

Risinger FO, Brown MM, Doan AM, Oakes RA (1998). Mouse strain differences in oral operant ethanol reinforcement under continuous access conditions. Alcohol Clin Exp Res 22: 677-684.

Risinger FO, Doan AM, Vickrey AC (1999). Oral operant ethanol self-administration in $5-\mathrm{HT}_{1 \mathrm{~b}}$ knocokout mice. Behav Brain Res 102: 211-215.

Roberts AJ, Heyser CJ, Koob GF (1999). Operant self-administration of sweetened versus unsweetened ethanol: effects on blood alcohol levels. Alcohol Clin Exp Res 23: 1151-1157.

Roberts JC, Reavill C, East SZ, Harrison PJ, Patel S, Routledge C et al (2002). The distribution of 5-HT(6) receptors in rat brain: an autoradiographic binding study using the radiolabelled 5-HT(6) receptor antagonist $\left[{ }^{(125)} \mathrm{I}\right] \mathrm{SB}-258585$. Brain Res 934: 49-57.

Rodd-Henricks ZA, McKinzie DL, Melendez RI, Berry N, Murphy JM, McBride WJ (2003). Effects of serotonin-3 receptor antagonists on the intracranial self-administration of ethanol within the ventral tegmental area of Wistar rats. Psychopharmacology (Berl) 165: 252-259.

Rogers DC, Hagan JJ (2001). 5- $\mathrm{HT}_{6}$ receptor antagonists enhance retention of a water maze task in the rat. Psychopharmacology (Berl) 158: 114-119.

Roth BL, Craigo SC, Choudhary MS, Uluer A, Monsma Jr FJ, Shen $\mathrm{Y}$ et al (1994). Binding of typical and atypical antipsychotic agents to 5-hydroxytryptamine-6 and 5-hydroxytryptamine-7 receptors. J Pharmacol Exp Ther 268: 1403-1410.

Routledge C, Price GW, Bromidge SM, Moss SF, Newman G, Riley $\mathrm{T}$ et al (1999). Characterisation of SB-271046, a potent and selective $5-\mathrm{HT}_{6}$ receptor antagonist. Br J Pharmacol 127: $21 \mathrm{P}$.

Ruat M, Traiffort E, Arrang JM, Tardivel-Lacombe J, Diaz J, Leurs $\mathrm{R}$ et al (1993). A novel rat serotonin (5- $\left.\mathrm{HT}_{6}\right)$ receptor: molecular cloning, localization and stimulation of cAMP accumulation. Biochem Biophys Res Commun 193: 268-276.

Russell MG, Dias R (2002). Memories are made of this (perhaps): a review of serotonin 5-HT(6) receptor ligands and their biological functions. Curr Top Med Chem 2: 643-654.

Sambrook J, Fritsch EF, Maniatis T (2001). Molecular Cloning, A Laboratory Manual, 3rd edn. Cold Spring Harbor Laboratory: Cold Spring Harbor, NY.

Samson HH, Pfeiffer AO, Tolliver GA (1998). Oral ethanol selfadministration in rats: models of alcohol-seeking behavior. Alcohol Clin Exp Res 12: 591-598.

Shinkai T, Ohmori O, Kojima H, Terao T, Suzuki T, Abe K (1999). Association study of the $5-\mathrm{HT}_{6}$ receptor gene in schizophrenia. Am J Med Genet (Neuropsych Genet) 88: 120-122.

Sleight AJ, Boess FG, Bos M, Levet-Trafit B, Riemer C, Bourson A (1998). Characterization of Ro 04-6790 and Ro 63-0563: potent and selective antagonists at human and rat $5-\mathrm{HT}_{6}$ receptors. $\mathrm{Br} \mathrm{J}$ Pharmacol 124: 556-562.

Sleight AJ, Monsma Jr FJ, Borroni E, Austin RH, Bourson A (1996). Effects of altered 5-ht ${ }_{6}$ expression in the rat: functional studies using antisense oligonucleotides. Behav Brain Res 73: 245-248.

Stean TO, Hirst WD, Thomas DR, Price GW, Rogers D, Riley G et al (2002). Pharmacological profile of SB-357134: a potent, selective, brain penetrant, and orally active 5-HT(6) receptor antagonist. Pharmacol Biochem Behav 71: 645-654.

Svartengren J, Axelsson-Lendin P, Edling N, Fhölenhag K, Isacson $\mathrm{R}$, Hillegaart $\mathrm{V}$ et al (2004). The Selective Serotonin $5-H T_{6}$ Receptor Antagonist BVT5182 Decreases Food Intake and Body Weight in Both Rats and Mice. Abstract/Viewer/Itinerary Planner. Society for Neuroscience: Washington, DC. Online.

Thiele TE, Miura GI, Marsh DJ, Bernstein IL, Palmiter RD (2000). Neurobiological responses to ethanol in mutant mice lacking neuropeptide Y or the Y5 receptor. Pharmacol Biochem Behav 67: 683-691.

Thome J, Retz W, Baader M, Pesold B, Hu M, Cowen M et al (2001). Association analysis of $H T R_{6}$ and $H T R_{2 A}$ polymorphisms in sporadic Alzheimer's disease. J Neural Transm 108: $1175-1180$

Tomkins DM, Joharchi N, Tampakeras M, Martin JR, Wichmann J, Higgins GA (2002). An investigation of the role of 5-HT(2C) receptors in modifying ethanol self-administration behaviour. Pharmacol Biochem Behav 71: 735-744.

Tsai S-J, Chiu H-J, Want Y-C, Hong C-J (1999a). Association study of serotonin- 6 receptor variant $(\mathrm{C} 267 \mathrm{~T})$ with schizophrenia and aggressive behavior. Neurosci Lett 271: 135-137.

Tsai S-J, Liu H-C, Liu T-Y, Want Y-C, Hong C-J (1999b). Association analysis of the $5-\mathrm{HT}_{6}$ receptor polymorphism C267T in Alzheimer's disease. Neurosci Lett 267: 139.

Unsworth CD, Molinoff PB (1994). Characterization of a 5hydroxytryptamine receptor in mouse neuroblastoma N18TG2 cells. J Pharmacol Exp Ther 269: 246-255.

Virkkunen M, Linnoila M (1996). Serotonin and glucose metabolism in impulsively violent alcoholic offenders. In: Stoff DM, 
Cairns RB (eds). Aggression and Violence: Genetic, Neurobiological, and Biosocial Perspectives. Lawrence Erlbaum: Mahwah, NJ. pp 87-100.

Ward RP, Hamblin MW, Lachowicz JE, Hoffman BJ, Sibley DR, Dorsa DM (1995). Localization of serotonin subtype 6 receptor messenger RNA in the rat brain by in situ hybridization histochemistry. Neuroscience 64: 1105-1111.

Weiss F, Porrino LJ (2002). Behavioral neurobiology of alcohol addiction: recent advances and challenges. J Neurosci 22: 3332-3337.

West MW, Kalmus G, Myers RD (1998). Limited access to ethanol in genetic drinking rats is suppressed while feeding is enhanced by the mixed 5- $\mathrm{HT}_{1 \mathrm{~A}}$ agonist/5- $\mathrm{HT}_{2 \mathrm{~A}}$ antagonist FG5938. Pharmacol Biochem Behav 60: 823-828.

Wilson AW, Costall B, Neill JC (2000). Manipulation of operant responding for an ethanol-paired conditioned stimulus in the rat by pharmacological alteration of the serotonergic system. J Psychopharmacol 14: 340-346.
Woolley ML, Bentley JC, Sleight AJ, Marsden CA, Fone KC (2001). A role for $5-\mathrm{ht}_{6}$ receptors in retention of spatial learning in the Morris water maze. Neuropharmacology 41: 210-219.

Woolley ML, Marsden CA, Fone KCF (2004). 5-ht ${ }_{6}$ receptors. Curr Drug Targets - CNS Neurol Disorders 3: 59-79.

Yan QS (1999). Extracellular dopamine and serotonin after ethanol monitored with 5-minute microdialysis. Alcohol 19: 1-7.

Yoshimoto K, McBride WJ, Lumeng L, Li TK (1992). Alcohol stimulates the release of dopamine and serotonin in the nucleus accumbens. Alcohol 9: 17-22.

Yoshioka M, Matsumoto M, Togashi H, Mori K, Saito H (1998). Central distribution and function of $5-\mathrm{HT}_{6}$ receptor subtype in the rat brain. Life Sciences 62: 1473-1477.

Zhou FC, Bledsoe S, Lumeng L, Li TK (1991). Immunostained serotonergic fibers are decreased in selected brain regions of alcohol-preferring rats. Alcohol 8: 425-431.

Zhou FC, Pu CF, Murphy J, Lumeng L, Li TK (1994). Serotonergic neurons in the alcohol preferring rats. Alcohol 11: 397-403.

Supplementary information accompanies the paper on Neuropsychopharmacology website (http://www.nature.com/npp) 